\title{
THE PERMEABILITY OF THE 'BLOOD-TESTIS' BARRIER TO FERROCYANIDE
}

\author{
A. G. SEIGUER* AND R. E. MANGINI \\ Centro de Investigaciones sobre Reproduccion, \\ Facultad de Medicina, Buenos Aires, Argentina
}

(Received 11th March 1971)

\begin{abstract}
Summary. Ferrocyanide was detected histologically in adult rat testes by the Prussian blue reaction from $3 \mathrm{~min}$ to $3 \mathrm{hr}$ following intravenous injection. Ferrocyanide appeared in the lumen of the testicular blood vessels almost immediately following injection. After $10 \mathrm{~min}$, ferrocyanide was detected in most seminiferous tubule walls and, 20 to 30 min later, Prussian blue deposits were localized in the lumen and epithelium of some seminiferous tubules. The results suggest that the continuity of the extratubular and intratubular ferrocyanide compartments is interrupted in part by tubular wall structures. Possible explanations for the intratubular diffusion of ferrocyanide are discussed.
\end{abstract}

Ferrocyanide was reported to fulfil requirements for a substance which would measure the volume of the extracellular fluid (Kleeman, Epstein, Rubini \& Lamdin, 1955). At the doses employed in physiological studies, ferrocyanide does not penetrate red blood cells or produce haemolysis, and has no toxic effects (Kleeman et al., 1955; Kleeman \& Epstein, 1956). The demonstration of ferrocyanide by the Prussian blue reaction has been used to define the interstitial spaces in brain (Allen, 1955), muscle (Chase, 1959) and retina (Lasansky \& Wald, 1962). Ferrocyanide has also been used in diffusion kinetics and time course studies.

The aim of this work was to examine the permeability of the 'blood-testis' barrier (Setchell, Volgmayer \& Waites, 1969) to intravenously injected ferrocyanide. It has been suggested that the anatomical site of the permeability barrier in the testis may be located at the peritubular tissue (Setchell et al., 1969). Both the peritubular cells and junctions between Sertoli cells prevent intratubular penetration of tracers (Fawcett, Leak \& Heidger, 1970). Although several substances are unable to enter the seminiferous epithelium, there is selective entry of others, as indicated by the different rate at which tritiated water, urea and several ions in the circulation appear in the rete fluid (Setchell et al., 1969) and by the intratubular localization of intravenously injected fluorescein-conjugated FSH (Mancini, Castro \& Seiguer, 1967) or ferritincoupled FSH (Castro, Seiguer \& Mancini, 1970).

Adult male rats of the Wistar strain were used in this study. The rats were

* Present address: Institute of Molecular Evolution, University of Miami, Coral Gables, Florida. 
anaesthetized with ether, and quantities $(0.2 \mathrm{ml})$ of a $20 \%$ solution of ferrocyanide were injected into the tail veins. The ferrocyanide solution $(\mathrm{pH} \mathrm{6.8)}$ consisted of $19.0 \mathrm{~g}$ of the sodium salt and $1.1 \mathrm{~g}$ of the potassium salt dissolved in $100 \mathrm{ml}$ of distilled water (Chase, 1959). Under ether anaesthesia, the testes were removed at $3,10,15,20,30 \mathrm{~min}$ and 1,2 and $3 \mathrm{hr}$ after the injection. Three rats were used for each postinjection period. Pieces of testis were immersed in $4 \%$ formaldehyde containing $1 \%$ ferric ammonium sulphate and $1 \%$ hydrochloric acid (Lasansky \& Wald, 1962). After two changes of solution at 1 -hr intervals, fixation was continued in $4 \%$ formaldehyde for $24 \mathrm{hr}$, followed by dehydration and embedding in paraffin wax. Sections were observed with or without counterstaining ( $1 \%$ aqueous solution of neutral red). Other small pieces of testicular tissue were rapidly frozen and processed with the freeze-drying technique (Pearse, 1960). After embedding in vacuo the sections were stained for the Prussian blue reaction as described by Chase (1959). Controls consisted of testicular tissue from three adult rats which were not injected with ferrocyanide but which otherwise were treated as described above.

No relevant differences in the distribution of the Prussian blue stain were observed between fixed or unfixed, freeze-dried preparations. A light blue precipitate appeared in the lumen of arteries, arterioles and capillaries $3 \mathrm{~min}$ after injection. Venules and capillaries showed larger intraluminal aggregations 5 min after injection (Pl. 1, Fig. 1). Extravascular precipitates were seen around capillaries and venules from $5 \mathrm{~min}$ after injection and, by $10 \mathrm{~min}$ after injection, a considerable and irregularly defined diffusion of the stain from the perivascular areas was noticed (Pl. 1, Fig. 2). Deposits appeared to be concentrated in seminiferous tubule walls (Pl. 1, Figs. 3, 4). These peritubular deposits were frequently seen either as small accumulations or staining all of the structures of the tubular wall (PI. 1, Fig. 3). In some instances, heavy deposits obscured the seminiferous tubule wall structures (PI. 1, Fig. 4). By 20 to $30 \mathrm{~min}$ after the injection, some tubules (roughly 10 to $20 \%$ per section) exhibited intratubular deposits. Prussian blue aggregates were frequently seen in the lumen of the seminiferous tubules (Pl. 1, Fig. 5). Frequently, the Sertoli cell body was partially or totally covered with a diffuse stain (Pl. 1, Fig. 6). The intratubular

\section{EXPLANATION OF PLATE 1}

All micrographs, except Fig. 6, were taken from sections without counterstaining. The sections were obtained from fixed tissue.

FIG. 1. Prussian blue deposits (in black) are seen filling the lumen of vessels in between two seminiferous tubules $5 \mathrm{~min}$ after the injection. $\times 640$.

Fig. 2. Extravascular deposits are seen between two seminiferous tubules $10 \mathrm{~min}$ after the injection. $\times 520$.

Frg. 3. A portion of the seminiferous tubule wall with intense Prussian blue deposits 15 min after the injection. Note the stain over all of the tubular wall structures $\times 730$. Fig. 4. Large ferrocyanide accumulations in the wall of two seminiferous tubules $15 \mathrm{~min}$ after the injection $\times 780$.

Fig. 5. Prussian blue deposits are seen in the seminiferous tubule lumen $30 \mathrm{~min}$ after the injection $\times 320$.

FIG. 6. Prussian blue deposits are seen over part of the inner peritubular cell layer (arrowheads) 30 min after the injection. Other deposits partially stain the Sertoli cell cytoplasm (arrows). Section counterstained with $1 \%$ neutral red. $\times 1280$. 


\section{PLATE 1}
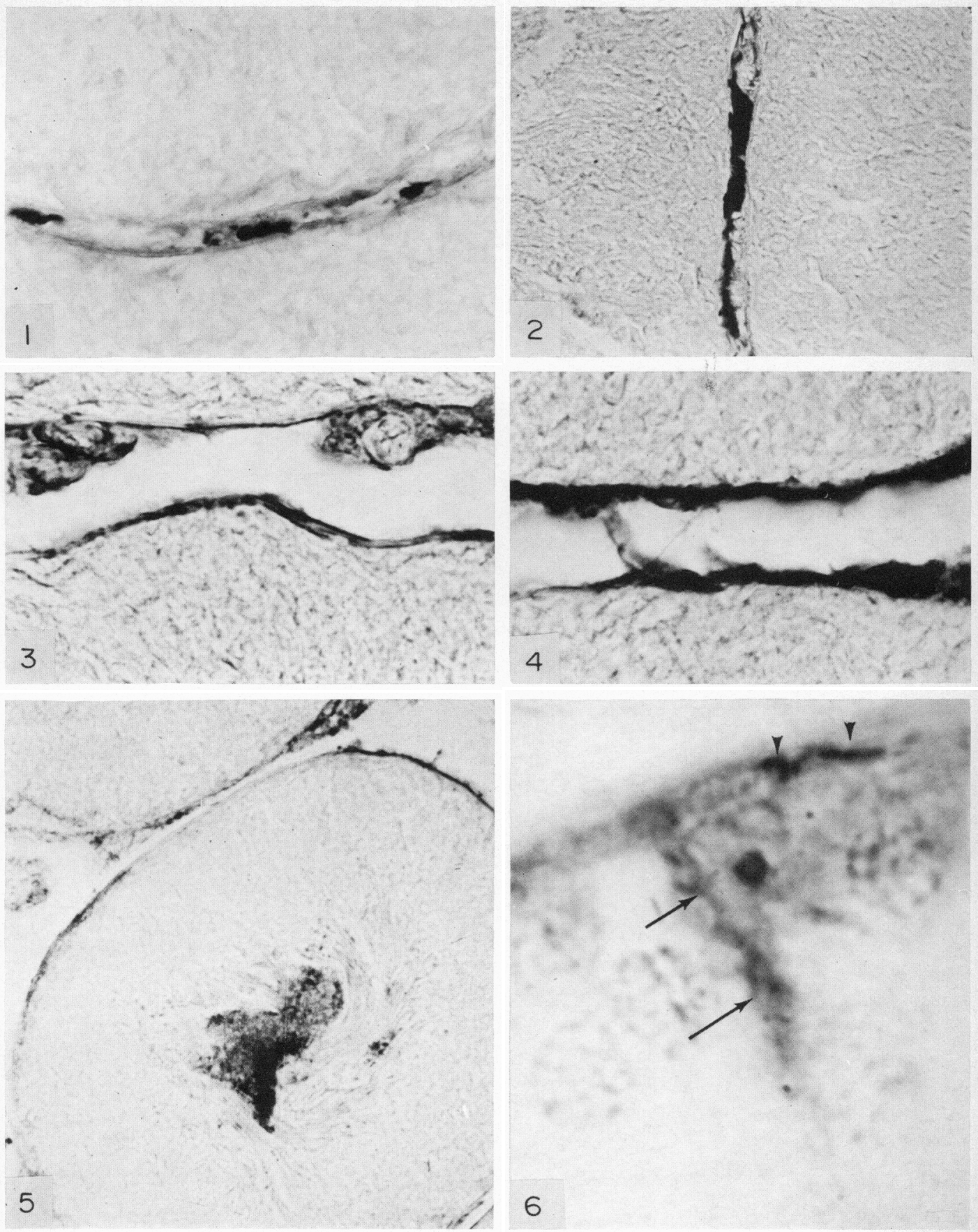

(Facing p. 270) 
aggregations tended to decrease between 60 and $90 \mathrm{~min}$ after the injection. Occasionally, they were still detected after $2 \mathrm{hr}$, at which time, several peritubular areas showed discrete precipitates. The peritubular areas also contained blue particles $3 \mathrm{hr}$ after injection. Prussian blue precipitates were absent in sections from the control group of animals.

Precise localization of histological tracers can be difficult to achieve due to diffusion post mortem of the tracer during immersion in the fixative. Because of the slow penetration of the fixative, ferrocyanide might diffuse and precipitate at the site of the greatest concentration of the ferric salt. The freeze-drying technique has been reported to preserve the distribution of injected ferrocyanide (Gersh \& Stieglitz, 1934; Chase, 1959). The fact that we found the same pattern of localization when ferrocyanide was detected in situ in unfixed, freeze-dried tissue suggests that the distribution observed after fixation is not a diffusion artifact. The possibility of some diffusion occurring during incubation after the freeze-drying procedure, however, cannot be completely discounted.

The early high rate of diffusion of ferrocyanide through the testicular vessels is in accordance with data utilizing dyes (Kormano, 1967, 1968) or serum proteins (Mancini, Vilar, Alvarez \& Seiguer, 1965). Most of the extravascular serum proteins may be drained through the intertubular lymphatic sinusoids (Cowie, Lascelles \& Wallace, 1964; Fawcett, Heidger \& Leak, 1969). Ferrocyanide may also follow this route. Due to the existence of a time lag between the extravascular diffusion and the intratubular detection of the tracer and the fact that not all the tubules exhibited intratubular ferrocyanide deposits, it seems reasonable to assume that the intertubular and intratubular ferrocyanide compartments are not freely communicating. The results indicate that in the rat the prevention of intratubular diffusion of ferrocyanide may be due to the peritubular tissue. This view is consistent with recent studies which showed that the anatomical site of the blood-testis barrier may be related to the peritubular contractile cells (Fawcett et al., 1970). That the seminiferous tubules are not completely excluded by the peritubular cells is supported by the fact that some tracers penetrate into the intercellular spaces of the seminiferous epithelium although junctions between adjacent Sertoli cells prevent further diffusion (Fawcett et al., 1970; Dym \& Fawcett, 1970). Localization of tracers within the Sertoli cell cytoplasm has also recently been demonstrated in the seminiferous tubules of rat testis incubated in vitro (Vilar \& Mancini, 1970). Incorporation of foreign particles into the Sertoli cell may be due to phagocytosis. Under normal circumstances, however, the Sertoli cells of the rat testis possess limited phagocytic properties. Incorporation and storage of dyes and particles by Sertoli cells were only observed in degenerative testis or when the substances were retrogradely introduced through the rete testis (Clegg \& MacMillan, 1965; Carr, Clegg \& Meek, 1968). The question arises whether some ferrocyanide deposits were in the Sertoli cell cytoplasm, the intercellular spaces or both. If the intercellular path to the tubular lumen is blocked by junctions between Sertoli cells, it is conceivable that luminal localization of tracers, as shown here, may result from intracellular diffusion through the Sertoli cell as previously suggested (Mancini et al., 1965). 
This study has been supported by a grant from the Population Council, Inc., New York.

\section{REFERENCES}

Alden, J. N. (1955) Extracellular space in the central nervous system. Archs Neurol. Psychiat., Chicago, $73,241$.

Garr, I., GlegG, E. J. \& MeEk, G. A. (1968) Sertoli cells as phagocytes: an electron microscopic study. F. Anat. 102, 501.

Castro, A. E., Seiguer, A. C. \& Mancini, R. E. (1970) Electron microscope study of the localization of labeled gonadotropins in the Sertoli and Leydig cells of the rat testis. Proc. Soc. exp. Biol. Med. 133, 582.

Ghase, W. H. (1959) Extracellular distribution of ferrocyanide in muscle. Archs Path. 67, 525.

CleGG, E. J. \& MacMillan, E. N. (1965) The uptake of vital dyes and particulate matter by the Sertoli cells of the rat testis. 7 . Anat. 99, 219.

Cowie, A. T., Lascelles, A. K. \& Wallace, J. C. (1964) Flow and protein content of testicular lymph in conscious rams. F. Physiol., Lond. 171, 776.

DYM, M. \& FAWGETT, D. W. (1970) Ultrastructural observations on the penetration of lanthanum into the germinal epithelium of the rat testis. Anat. Rec. 161, 301.

FawcetT, D. W., Heidger, P. M. \& Leak, L. V. (1969) Lymph vascular system of the interstitial tissue of the testis as revealed by electron microscopy. F. Reprod. Fert. 19, 109.

FAwcetT, D. W., Leak, L. V. \& Heidger, P. M. (1970) Electron microscopic observations on the structural components of the blood-testis barrier. F. Reprod. Fert. Suppl. 10, 105.

Gersh, I. \& Stieglitz, E. J. (1934) Histochemical studies on the mammalian kidney. I. The glomerular elimination of ferrocyanide in the rabbit, and some related problems. Rnat. Rec. 58, 349.

Kleeman, C. R. \& Epstein, F. H. (1956) Fate and distribution of $\mathrm{Fe}^{59}$ labelled ferrocyanide in humans and dogs. Proc. Soc. exp. Biol. Med. 93, 228.

Klemman, G. R., Epstein, F. H., Rubini, M. E. \& Lamdin, E. (1955) Initial distribution and fate of ferrocyanide in dogs. Am. F. Physiol. 182, 548.

Kormano, M. (1967) Dye permeability and alkaline phosphatase activity of testicular capillaries in the postnatal rat. Histochemie, 9, 327.

Kormano, M. (1968) Penetration of intravenous trypan blue into the rat testis and epididymis. Acta histochem. 30, 133.

LASANSKY, A. \& WALD, F. (1962) The extracellular space in the toad retina as defined by the distribution of ferrocyanide. F. Cell Biol. 15, 463.

Mancini, R. E., Gastro, A. E. \& Seiguer, A. G. (1967) Histologic localization of follicle-stimulating and luteinizing hormones in the rat testis. F. Histochem. Cytochem. 15, 516.

Mancini, R. E., Vilar, A., Alvarez, B. \& Seiguer, A. C. (1965) Extravascular and intratubular diffusion of labeled serum proteins in the rat testis. J. Histochem. Cytochem. 13, 376.

Pearse, A. G. E. (1960) Histochemistry, 2nd edn, p. 25. Little Brown, Boston.

Setchell, B. P., Volgmayr, J. K. \& Wartes, G. M. H. (1969) A blood-testis barrier restricting passage from blood into rete testis fluid but not into lymph. F. Physiol., Lond. 200, 73.

VILAR, O. \& MANcINI, R. E. (1970) In vivo and in vitro intratubular diffusion and uptake of different substances by rat Sertoli cells. Acta europ. Fertil. 2, 193. 